\title{
Studies in Penicillin Treatment of Syphilis
}

By R. C. ARNOLD, M. D., J. C. CUTLER, M. D.,

R. D, WRIGHT, M. D., and S. LEVITAN, M. D.

More than 7 years have elapsed since the efficacy of penicillin in the treatment of early syphilis. was first reported (1). In this relatively short period, penicillin has been adopted throughout the United States, and much of the world, for the treatment of all stages of syphilis. Concepts of epidemiology, immunology, serology, and treatment have been radically altered. The hazards of the antisyphilitic therapies of the past have been eliminated; the treatment period has been shortened from years to days; and a modern type of "therapia sterilisans magna" has been realized. These factors have brought about many necessary adjustments as well as advantageous developments in the administrative, clinical, and educational phases of venereal disease control.

Of the several specifications for an ideal therapy, cure of all patients is of primary importance. Unfortunately, this goal has not yet

Dr. Arnold is chief of the technical services branch, National Heart Institute, of the $\mathrm{Na}$ tional Institutes of Health, Public Health Service. Dr. Cutler is chief of the technical aids and services branch, Division of Venereal Disease, Public Health Service. Dr. Wright is with the University of Virginia at Charlottesville. Dr. Levitan is chief of the yaws and syphilis control program of the United Nations International Children's Emergency Fund, World Health Organization, Port-au-Prince, Haiti.

The authors of this paper have all served at the venereal disease research laboratory of the Public Health Service, where these studies were conducted. The laboratory was transferred from Staten Island, N. Y., to Atlanta, Ga., in March 1950. been attained. All treatment schedules, both old and new, which have been used on 100 or more patients with early syphilis have had true failures or relapses in addition to established reinfections. Nevertheless, penicillin excellently fulfills the aims of a practical therapy - to cure with safety, simplicity, and economy a high percentage of those treated in the early stages.

During these formative 7 years there have been many improvements in the antibiotic agent and in the complementary vehicle for administration. The subsequent adoption in rapid succession of various therapeutic schedules and drug refinements has made comparative evaluation difficult; but it has provided comprehensive experimental data upon which the optimal time-dose relationship can be established. From the variety of studies thus engendered it has become clear that penicillin therapy can safely and quickly eliminate the early infectiousness, as well as the potential late complications of the disease, in all who respond to standard treatment. Only a small minority need individualized re-treatment at a later date.

This paper reviews the results of the studies in developing penicillin therapies undertaken from 1943 to 1950 in the venereal disease research laboratory. Throughout this period our patients were predominantly young white males; only about 3 percent of the total study group were females. All clinical diagnoses were confirmed by laboratory findings and, so far as is known, no previous therapy for early syphilis had been received by any of the patients included in the study groups. The ratio of primary to secondary syphilis is indicated in the accompanying tables for the various treatment schedules. All patients were hospitalized for pretreatment diagnostic study, for therapy, and, whenever possible, for special post-treat- 
ment examination when reinfection or treatment failure was suspected or when serologic reactivity was unusual.

\section{Early Penicillin Schedules}

After animal experimentation indicated that penicillin possessed spirocheticidal activity, a human pilot study was initiated in June 1943 (1). In this study four men with darkfieldpositive primary syphilis received $1,200,000$ units of amorphous penicillin in aqueous solution, in 48 doses of 25,000 units each, administered intramuscularly at 4-hour intervals for 8 days. When the four men were re-examined 6 years later, detailed clinical examinations and serologic studies were negative (2). Three of the men had maintained seronegativity since the second or third post-treatment month. The fourth had been clinically negative 10 days after therapy and serologically negative in a battery of diagnostic tests at 71 days. The negative findings persisted up to 286 post-treatment days, when his serology showed strongly positive; clinical examination revealed a new darkfield-positive chancre on the lip, and an acute gonococcal urethritis. Following a second course of penicillin, the clinical manifestations disappeared and the blood tests reverted to negativity.

These four patients, as well as many others, have been successfully treated with aqueous penicillin, as indicated by 36 or more months of observation. With each of the several timedosage combinations which have been tried, a good proportion of observed patients quickly reached and maintained both clinical and serologic negativity. Although failure rates in certain schedules were too high for practical purposes, the over-all picture confirms the efficacy and adaptability of penicillin in the treatment of early syphilis.

\section{Aqueous Penicillin Schedules}

The second treatment schedule used at this laboratory consisted of 20,000 units of aqueous amorphous penicillin administered intramuscularly every 3 hours for a total of 60 doses, or $1,200,000$ units (table 1, schedule A). An early review of this schedule indicated that it might be unsatisfactory (3) ; and by 21 post-treatment months a cumulative re-treatment rate of 32.8 percent among the secondary syphilis patients confirmed the earlier decision to seek a more effective regimen.

The total dosage was doubled for the next schedule : 40,000 units of penicillin was administered intramuscularly every 3 hours for 60 doses, or $2,400,000$ units. The cumulative retreatment rate for secondary syphilis patients was 20.1 percent by 21 months (table 1 , schedule B). It should be pointed out that the numbers of patients so far treated and observed were small in each diagnostic category, which made comparison of rates somewhat difficult between schedules. Nevertheless, in this latter schedule, the re-treatment rates as well as the seronegativity rates among observed patients showed, in general, considerable improvement over the previous schedule. In addition, it can be stated that among our predominantly male patients there were proportionately fewer clinical and serologic failures observed with $2,400,000$ units than with 1,200,000 units. Space limitations, however, do not permit showing the reasons for re-treatment on the accompanying tables. Sternberg and Leifer (4) reported good results with 2,400,000 units of amorphous penicillin administered to a large group of young males on the same time-dosage regimen.

Elsewhere, evaluation studies by the Division of Venereal Disease of the Public Health Service, based exclusively on patients treated for secondary syphilis, showed similar cumulative re-treatment rates by 21 months : 27.6 percent with $1,200,000$ units, and 22.4 percent with $2,400,000$ units of aqueous amorphous penicillin (5). However, these studies included much larger groups of patients, both male and female, white and nonwhite, drawn from several clinics. On such a basis, it became clear that the larger dosage of amorphous penicillin offered no essential advantages over the smaller dosage.

In the present report, we have used the method of statistical evaluation developed and employed by the Division of Venereal Disease, Public Health Service (6). However, it should be remembered that our patients were predominantly young white males-a factor which might be expected to produce differences from 
Table 1. Treatment of early syphilis with amorphous penicillin

\begin{tabular}{|c|c|c|c|c|c|c|c|c|c|}
\hline \multirow{2}{*}{$\begin{array}{l}\text { Observation period } \\
\text { (months) }\end{array}$} & \multicolumn{3}{|c|}{ Seronegative primary } & \multicolumn{3}{|c|}{ Seropositive primary } & \multicolumn{3}{|c|}{ Secondary } \\
\hline & $\begin{array}{c}\text { Total } \\
\text { cases } \\
\text { observed }\end{array}$ & $\begin{array}{c}\text { Cumulative } \\
\text { percent } \\
\text { re-treated }\end{array}$ & $\begin{array}{c}\text { Percent } \\
\text { sero- } \\
\text { negative }\end{array}$ & $\begin{array}{c}\text { Total } \\
\text { cases } \\
\text { observed }\end{array}$ & $\begin{array}{c}\text { Cumulative } \\
\text { percent } \\
\text { re-treated }\end{array}$ & $\begin{array}{c}\text { Percent } \\
\text { sero- } \\
\text { negative }\end{array}$ & $\begin{array}{c}\text { Total } \\
\text { cases } \\
\text { observed }\end{array}$ & $\begin{array}{c}\text { Cumulative } \\
\text { percent } \\
\text { re-treated }\end{array}$ & $\begin{array}{c}\text { Percent } \\
\text { sero- } \\
\text { negative }\end{array}$ \\
\hline
\end{tabular}

A. $1,200,000$ units $\left(20,000\right.$ units every 3 hours for $7 \frac{1}{2}$ days)

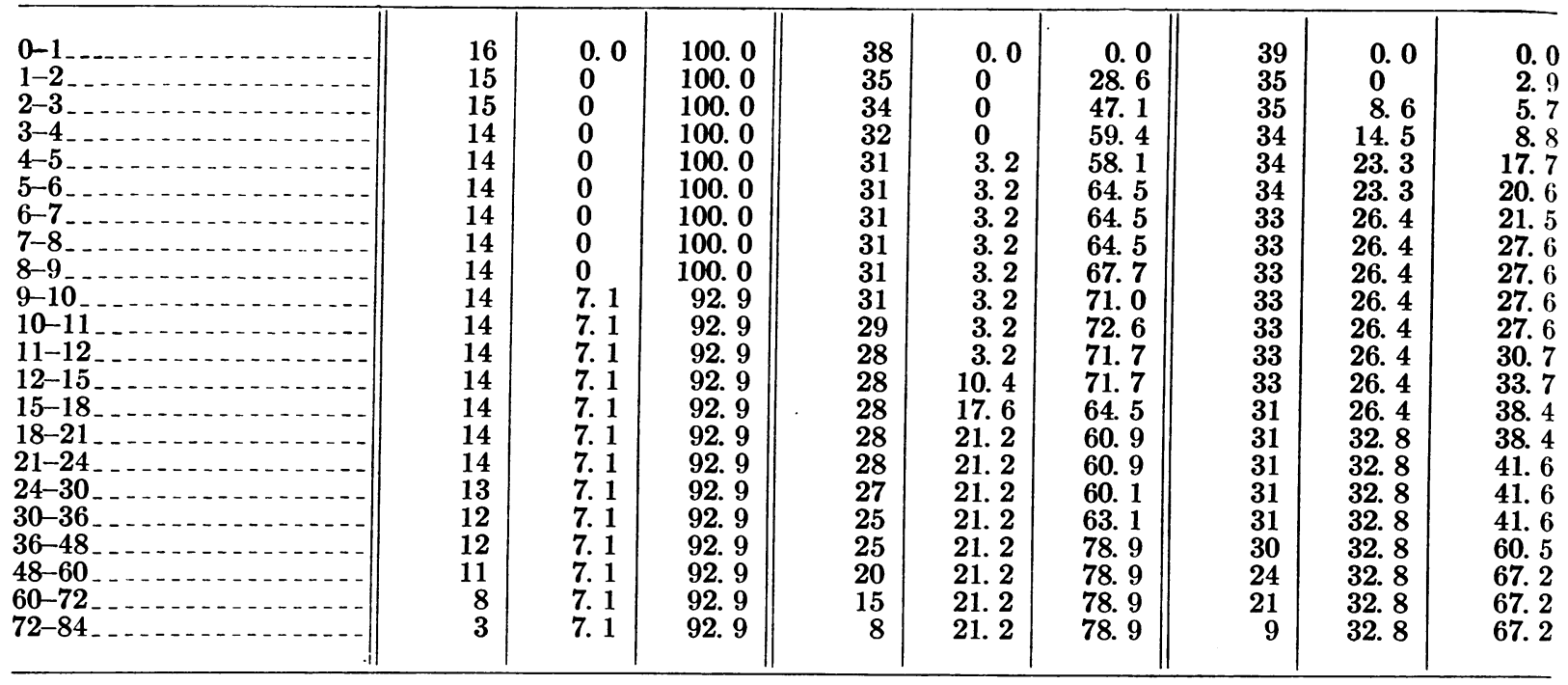

B. $2,400,000$ units $(40,000$ units every 3 hou:s for $71 / 2$ days)

\begin{tabular}{|c|c|c|c|c|c|c|c|c|c|}
\hline $\begin{array}{l}0-120 \\
1-2 \\
2-3 \\
3-4 \\
4-5 \\
5\end{array} 6$ & $\begin{array}{r}26 \\
24 \\
23 \\
23 \\
23 \\
22 \\
21 \\
19 \\
19 \\
17 \\
17 \\
17 \\
17 \\
16 \\
16 \\
16 \\
14 \\
13 \\
10 \\
8 \\
3\end{array}$ & $\begin{array}{l}4.2 \\
8.6 \\
8.6 \\
8.6 \\
8.6 \\
8.6 \\
8.6 \\
8.6 \\
8.6 \\
8.6 \\
8.6 \\
8.6 \\
8.6 \\
8.6 \\
8.6 \\
8.6 \\
8.6 \\
8.6 \\
8.6 \\
8.6 \\
8.6\end{array}$ & $\begin{array}{r}\text { 100. } 0 \\
83.3 \\
87.1 \\
87.1 \\
87.1 \\
86.9 \\
86.7 \\
86.1 \\
86.1 \\
85.8 \\
85.8 \\
85.8 \\
91.5 \\
91.5 \\
91.5 \\
91.5 \\
91.5 \\
91.5 \\
91.5 \\
91.5 \\
91.5\end{array}$ & $\begin{array}{r}38 \\
37 \\
37 \\
37 \\
37 \\
32 \\
31 \\
30 \\
30 \\
29 \\
29 \\
28 \\
27 \\
27 \\
21 \\
19 \\
19 \\
18 \\
17 \\
16 \\
6\end{array}$ & $\begin{array}{l}0.0 \\
0 \\
2.7 \\
2.7 \\
2.7 \\
2.7 \\
2.7 \\
2.7 \\
2.7 \\
2.7 \\
2.7 \\
2.7 \\
2.7 \\
6.4 \\
6.4 \\
6.4 \\
6.4 \\
6.4 \\
6.4 \\
6.4 \\
6.4\end{array}$ & $\begin{array}{l}0.0 \\
18.9 \\
43.2 \\
64.9 \\
73.0 \\
81.6 \\
81.1 \\
83.9 \\
87.2 \\
90.3 \\
90.3 \\
90.1 \\
89.8 \\
86.1 \\
84.2 \\
83.2 \\
88.4 \\
88.1 \\
87.7 \\
87.3 \\
93.6\end{array}$ & $\begin{array}{r}34 \\
32 \\
31 \\
31 \\
30 \\
30 \\
30 \\
27 \\
26 \\
25 \\
25 \\
25 \\
23 \\
23 \\
21 \\
20 \\
19 \\
15 \\
15 \\
13 \\
6\end{array}$ & $\begin{array}{l}0.0 \\
0 \\
6.5 \\
13.0 \\
16.3 \\
16.3 \\
16.3 \\
16.3 \\
20.1 \\
20.1 \\
20.1 \\
20.1 \\
20.1 \\
20.1 \\
20.1 \\
20.1 \\
20.1 \\
20.1 \\
20.1 \\
20.1 \\
20.1\end{array}$ & $\begin{array}{r}\text { 0. } 0 \\
0 \\
6.5 \\
16.1 \\
30.1 \\
33.5 \\
40.2 \\
43.7 \\
45.7 \\
48.0 \\
48.0 \\
48.0 \\
57.7 \\
62.2 \\
65.8 \\
65.0 \\
69.3 \\
79.9 \\
79.9 \\
79.9 \\
79.9\end{array}$ \\
\hline
\end{tabular}

results shown in other studies in evaluation of a particular therapy. One report on the probable influence of the factors of race, sex, and stage of syphilis on results of therapy $(7)$ indicates that white males will usually have a lower re-treatment rate than Negro males in the two primary stages of syphilis; that in white male patients the cumulative re-treatment rate for secondary syphilis will be higher than the rates observed in seronegative and seropositive primary syphilis; but that no significant differences were observed between the four groups (white and Negro, male and female) in patients treated for secondary syphilis.

Experiments with aqueous amorphous penicillin solutions indicated that when the interval 
Table 1. Treatment of early syphilis with amorphous penicillin-Continued

\begin{tabular}{|c|c|c|c|c|c|c|c|c|c|}
\hline \multirow[b]{2}{*}{$\begin{array}{c}\text { Observation period } \\
\text { (months) }\end{array}$} & \multicolumn{3}{|c|}{ Seronegative primary } & \multicolumn{3}{|c|}{ Seropositive primary } & \multicolumn{3}{|c|}{ Secondary } \\
\hline & $\begin{array}{c}\text { Total } \\
\text { cases } \\
\text { observed }\end{array}$ & $\begin{array}{c}\text { percent } \\
\text { re-treated }\end{array}$ & $\begin{array}{c}\text { Percent } \\
\text { sero- } \\
\text { negative }\end{array}$ & $\begin{array}{c}\text { Total } \\
\text { cases } \\
\text { observed }\end{array}$ & $\left|\begin{array}{c}\text { Cumulative } \\
\text { percent } \\
\text { re-treated }\end{array}\right|$ & $\begin{array}{c}\text { Percent } \\
\text { sero- } \\
\text { negative }\end{array}$ & $\begin{array}{c}\text { Total } \\
\text { cases } \\
\text { observed }\end{array}$ & $\begin{array}{c}\text { Cumulative } \\
\text { percent } \\
\text { re-treated }\end{array}$ & $\begin{array}{c}\text { Percent } \\
\text { sero- } \\
\text { negative }\end{array}$ \\
\hline
\end{tabular}

C. 1,700,000 units (20,000 units every 2 hours for 7 days)

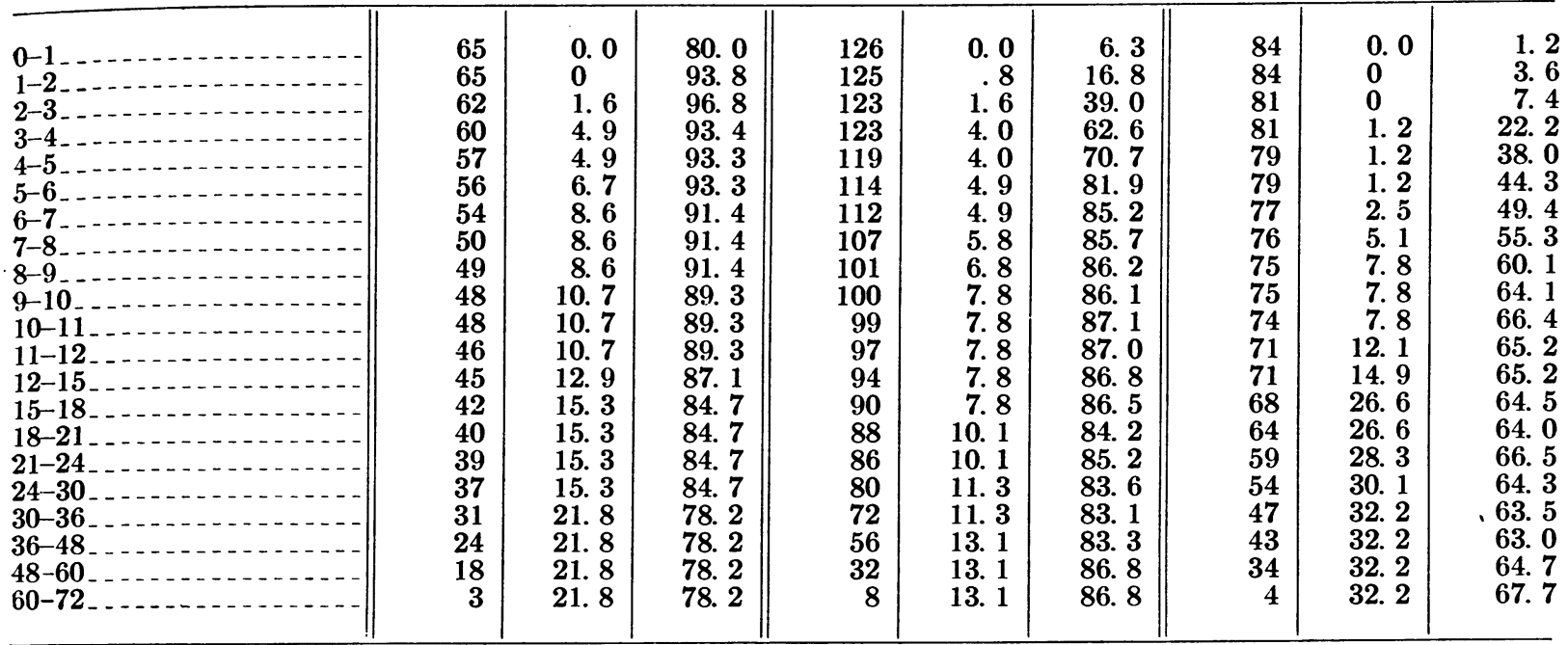

D. $3,400,000$ units $(40,000$ every 2 hours for 7 days)

\begin{tabular}{|c|c|c|c|c|c|c|c|c|c|}
\hline $\begin{array}{l}0-1 \\
2-2 \\
34-5 \\
56-6 \\
6-8\end{array}$ & $\begin{array}{r}87 \\
85 \\
84 \\
84 \\
83 \\
78 \\
77 \\
75 \\
74 \\
72 \\
72 \\
71 \\
68 \\
64 \\
60 \\
56 \\
52 \\
43 \\
33 \\
18 \\
4\end{array}$ & $\begin{array}{l}0 \\
0 \\
0 \\
1.2 \\
2.4 \\
3.7 \\
3.7 \\
3.7 \\
3.7 \\
7.9 \\
7.9 \\
7.9 \\
9.4 \\
9.4 \\
9.4 \\
9.4 \\
9.4 \\
9.4 \\
9.4 \\
9.4 \\
9.4\end{array}$ & $\begin{array}{l}65.5 \\
83.5 \\
97.6 \\
97.6 \\
96.4 \\
95.0 \\
95.0 \\
95.0 \\
95.0 \\
92.1 \\
92.1 \\
92.1 \\
90.7 \\
90.7 \\
90.7 \\
90.7 \\
90.7 \\
90.7 \\
90.7 \\
90.7 \\
90.7\end{array}$ & $\begin{array}{r}272 \\
270 \\
259 \\
255 \\
249 \\
246 \\
244 \\
231 \\
221 \\
219 \\
211 \\
209 \\
203 \\
195 \\
180 \\
164 \\
154 \\
129 \\
118 \\
49 \\
9\end{array}$ & $\begin{array}{l}0 \\
0 \\
0 \\
.8 \\
1.2 \\
1.2 \\
2.0 \\
2.4 \\
2.9 \\
3.8 \\
3.8 \\
3.8 \\
4.8 \\
5.3 \\
7.5 \\
7.5 \\
8.8 \\
8.8 \\
10.5 \\
12.5 \\
12.5\end{array}$ & $\begin{array}{l}2.6 \\
24.8 \\
51.7 \\
74.5 \\
82.7 \\
87.0 \\
89.4 \\
90.6 \\
91.2 \\
91.2 \\
92.4 \\
92.4 \\
91.8 \\
91.6 \\
90.8 \\
90.6 \\
89.2 \\
91.2 \\
89.5 \\
87.4 \\
87.5\end{array}$ & $\begin{array}{r}189 \\
189 \\
186 \\
183 \\
179 \\
177 \\
172 \\
168 \\
164 \\
160 \\
157 \\
151 \\
145 \\
139 \\
128 \\
120 \\
112 \\
98 \\
87 \\
43 \\
3\end{array}$ & 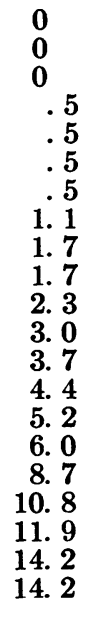 & $\begin{array}{r}1.1 \\
4.2 \\
12.9 \\
36.6 \\
55.3 \\
54.8 \\
61.6 \\
70.9 \\
73.8 \\
76.3 \\
79.1 \\
81.0 \\
83.2 \\
86.2 \\
86.9 \\
88.1 \\
86.8 \\
84.1 \\
84.6 \\
83.4 \\
85.7\end{array}$ \\
\hline
\end{tabular}

between injections was reduced from 3 hours to 2 hours more constant and higher penicillin blood levels could be maintained in a larger proportion of patients (8). Consequently, in the next investigative schedule the interval between injections was reduced: 20,000 units (amorphous) was given every 2 hours for 85 injections, to a total of $1,700,000$ units. By 21 post- treatment months the cumulative re-treatment rate for secondary syphilis under this schedule was 26.6 percent among observed patients (table 1, schedule $\mathrm{C}$ ).

Then a 3,400,000-unit schedule, consisting of 85 intramuscular injections of 40,000 units of aqueous amorphous penicillin every 2 hours, was tried (9). The cumulative re-treatment rate 
for secondary syphilis at the end of 21 months of observation was 5.2 percent among followed patients, and the seronegativity rate $(86.9$ percent) was good (table 1, schedule D). This schedule was considered to be effective, but the 7 days of hospitalization required for the completion of treatment and the frequency of injections-which necessitated costly medical supervision-were undesirable from an administrative viewpoint. Hence, the next step was to determine the fewest number of days in which the disease could be cured or how long and in what concentration penicillin had to be maintained in the body to obtain cure among the greatest possible percentage of patients.

The Chicago Intensive Treatment Center had meanwhile reported that early syphilis could be cured in about half the patients treated with massive aqueous penicillin therapy administered by intravenous drip for 24 hours (10). Although the adoption of such a schedule was not feasible because of its excessive failure rate, it was significant that even a small percentage of early syphilis in man could be cured with only 24 hours of aqueous penicillin therapy.

Experimental studies demonstrated that early syphilis in animals could be cured with aqueous penicillin administered for $12,18,24$, and 48 hours, respectively $(11,12)$. Many of the syphilitic animals were cured by 12 to 24 hours of continuous treatment; but maximum effectiveness was obtained with 72 hours of therapy. In other words, the cure rate rose sharply when adequate blood levels of penicillin were maintained in the animals for 72 hours.

On the basis of the assumption that the optimal duration of therapy for early syphilis in man-curative penicillin concentrations in the body-would be less than 8 days but more than 1, and on the basis of the information gained from the animal experiments, a 3-day schedule was established for clinical trial (13). The duration of therapy in this schedule (table 2 , schedule A) was 70 hours; duration of significant penicillin concentrations in the serum, at least 78 hours. Since the individual dose of 200,000 units was probably far in excess of the optimal dosage, it was believed that treatment failures could be attributed to shortened duration rather than to inadequate dosage of penicillin. The cumulative re-treatment rate for this schedule among secondary syphilis patients was only 4.0 percent at the end of 21 months of observation, indicating that in our experience early syphilis responds just as favorably to 3 days of treatment as to 7 days. This result demonstrated again that penicillin is effective as the sole therapeutic agent and that adequate penicillin schedules do not need the therapeutic support of the arsenic or heavymetal drugs.

In an effort to reduce further the time required for treatment, a 2-day schedule was evolved (table 2, schedule B). There was early evidence that 2 days of therapy would not be as effective as 3 days. The re-treatment rate by 6-month periods was 11.1 among secondary syphilis patients. This schedule was therefore abandoned.

The favorable response to 3 days of adequate penicillin serum concentration appeared to be the key to the solution of the time factor in the ambulatory management of syphilis, and to the efficient utilization of slowly absorbed penicillin salts in repository vehicles. Further studies were necessary to determine the minimum therapeutic dosage.

\section{Slowly Absorbed Penicillins}

To obviate the necessity of frequent injections of penicillin, investigators had been experimenting with vehicles which would slow the absorption rate of penicillin, and had developed sparingly soluble salts of the antibiotic. The initial success was scored by Romansky and Rittman (14) when they incorporated penicillin in peanut oil and beeswax. This product was quickly adopted for the treatment of early syphilis, with favorable results $\left(15,16,1^{n y}\right)$. In 1947 our experiments with the beryllium salts of penicillin showed excellent level-sustaining properties, but the investigation was shortly abandoned because of the danger of toxicity from the beryllium salts. Early in 1948, procaine penicillin $G$ in oil became available and, according to our understanding, received its first clinical application to the treatment of syphilis at the venereal disease research laboratory. Shortly after, Buckwalter and Dickison (18) introduced the principle for the most satisfactory of the 
Table 2. Treatment of early syphilis with aqueous crystalline penicillin $\mathbf{G}$

\begin{tabular}{|c|c|c|c|c|c|c|c|c|c|}
\hline \multirow{2}{*}{$\begin{array}{l}\text { Observation period } \\
\text { (months) }\end{array}$} & \multicolumn{3}{|c|}{ Seronegative primary } & \multicolumn{3}{|c|}{ Seropositive primary } & \multicolumn{3}{|c|}{ Secondary } \\
\hline & $\begin{array}{c}\text { Total } \\
\text { cases } \\
\text { observed }\end{array}$ & $\begin{array}{c}\text { Cumulative } \\
\text { percent } \\
\text { re-treated }\end{array}$ & $\begin{array}{c}\text { Percent } \\
\text { sero- } \\
\text { negative }\end{array}$ & $\begin{array}{c}\text { Tutal } \\
\text { cases } \\
\text { observed }\end{array}$ & $\begin{array}{c}\text { Cumulative } \\
\text { percent } \\
\text { re-treated }\end{array}$ & $\begin{array}{c}\text { Percent } \\
\text { sero- } \\
\text { negative }\end{array}$ & $\begin{array}{c}\text { Total } \\
\text { cases } \\
\text { observed }\end{array}$ & $\begin{array}{c}\text { Cumulative } \\
\text { percent } \\
\text { re-treated }\end{array}$ & $\begin{array}{c}\text { Percent } \\
\text { sero- } \\
\text { negative }\end{array}$ \\
\hline
\end{tabular}

A. $7,200,000$ units $(200,000$ units every 2 hours for 3 days)

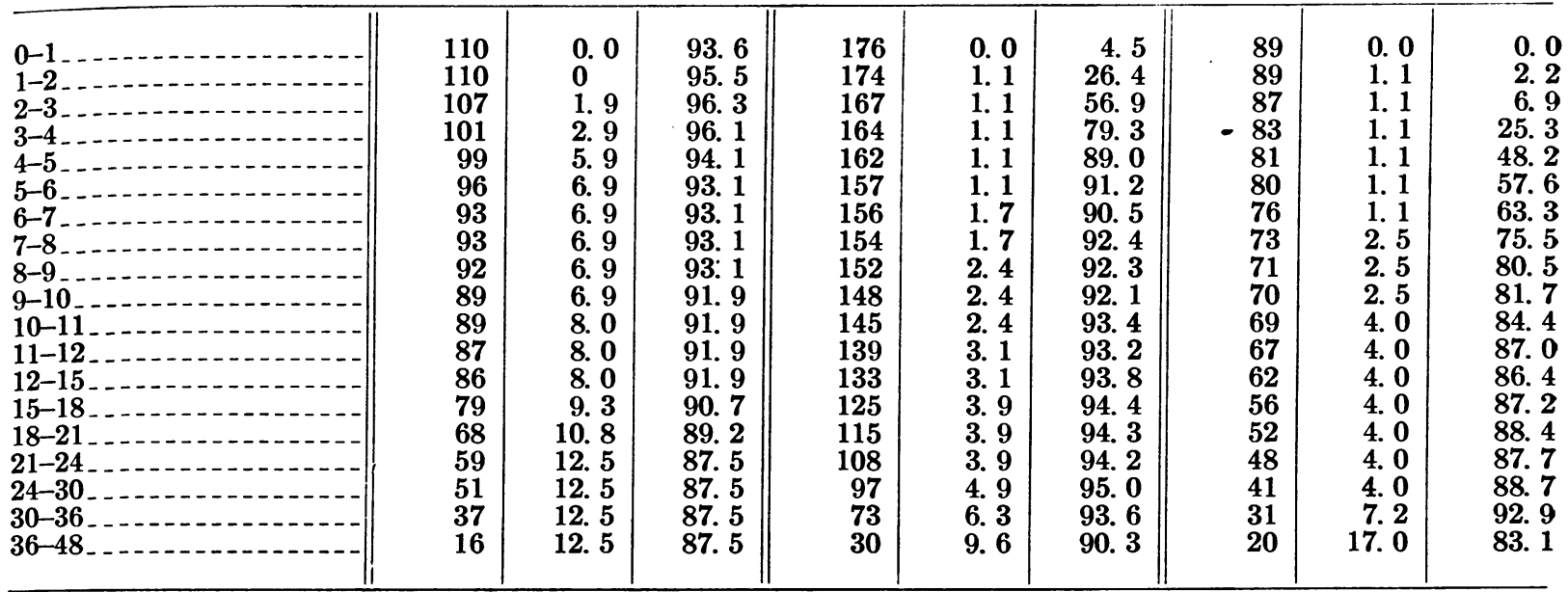

B. $7,200,00$ units $(300,000$ units every 2 hours for 2 days)

\begin{tabular}{|c|c|c|c|c|c|c|c|c|c|}
\hline $\begin{array}{l}0-120 \\
2-2 \\
3-4 \\
4-5\end{array}$ & $\begin{array}{l}19 \\
18 \\
16 \\
16 \\
16 \\
16 \\
15 \\
15 \\
15 \\
15 \\
15 \\
15 \\
15 \\
15 \\
15 \\
14 \\
10\end{array}$ & $\begin{array}{l}0.0 \\
0 \\
0 \\
0 \\
0 \\
0 \\
6.7 \\
6.7 \\
6.7 \\
6.7 \\
6.7 \\
6.7 \\
6.7 \\
6.7 \\
6.7 \\
6.7 \\
6.7\end{array}$ & $\begin{aligned} & \text { 78. } 9 \\
& 94.4 \\
& 93.8 \\
& 100.0 \\
& 100.0 \\
& 100.0 \\
& 93.3 \\
& 93.3 \\
& 93.3 \\
& 93.3 \\
& 93.3 \\
& 93.3 \\
& 93.3 \\
& 93.3 \\
& 93.3 \\
& 93.3 \\
& 93.3\end{aligned}$ & $\begin{array}{l}42 \\
42 \\
39 \\
38 \\
36 \\
35 \\
33 \\
32 \\
32 \\
32 \\
32 \\
31 \\
28 \\
25 \\
24 \\
20 \\
12\end{array}$ & 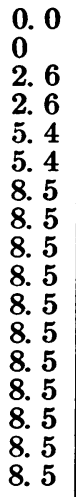 & $\begin{array}{l}2.4 \\
28.6 \\
69.2 \\
86.9 \\
89.1 \\
88.9 \\
91.6 \\
91.6 \\
91.6 \\
91.6 \\
91.6 \\
91.6 \\
91.6 \\
91.6 \\
91.6 \\
91.6 \\
91.6\end{array}$ & $\begin{array}{l}29 \\
29 \\
28 \\
27 \\
27 \\
27 \\
27 \\
27 \\
27 \\
27 \\
27 \\
25 \\
24 \\
24 \\
20 \\
16 \\
14\end{array}$ & $\begin{array}{c}0.0 \\
0 \\
0 \\
0 \\
11.1 \\
11.1 \\
11.1 \\
11.1 \\
11.1 \\
11.1 \\
11.1 \\
11.1 \\
11.1 \\
11.1 \\
11.1 \\
11.1 \\
11.1\end{array}$ & $\begin{array}{r}3.4 \\
3.4 \\
10.7 \\
29.6 \\
44.4 \\
55.6 \\
63.0 \\
63.0 \\
66.7 \\
74.1 \\
74.1 \\
76.8 \\
76.2 \\
76.2 \\
79.0 \\
82.5 \\
81.5\end{array}$ \\
\hline
\end{tabular}

sparingly soluble penicillin repository preparations in current use-procaine penicillin G in oil gelled with 2 percent aluminum monostearate.

An intensive study was made in the venereal disease research laboratory to determine the predictable results of the administration of varying amounts of this latest preparation. Seventy-two hours after single injections of 300,000 ( 1 cc.) and 600,000 units ( 2 cc.), detectable levels of penicillin were found in 97 and 96 percent, respectively, of the patients treated (table 3). Detectable levels were ob- served in some of the patients for longer periods, but it was felt that maintenance of levels beyond the seventy-second hour was not necessary.

In our first experimental schedule utilizing procaine penicillin in oil with 2 percent alumium monostearate, 600,000 units was administered intramuscularly once daily for 3 days (19). By this time we noted a distinct decrease in the numbers of patients available to us for inclusion in therapy evaluation studies. This was an encouraging trend, but the difficulty of finding suitable patients is reflected in table 4, 
Table 3. Penicillin levels of blood after single injection of procaine penicillin $\mathbf{G}$ in oil with 2 percent $(w / v)$ aluminum monostearate

\begin{tabular}{|c|c|c|c|c|c|c|}
\hline \multirow{2}{*}{$\begin{array}{l}\text { Dose of penicillin } \\
\text { (units) }\end{array}$} & \multirow{2}{*}{ Total patients } & \multirow{2}{*}{\begin{tabular}{|c} 
Percent of total patients \\
showing detectable levels \\
at 72 hours
\end{tabular}} & \multicolumn{4}{|c|}{$\begin{array}{l}\text { A verage penicillin blood levels (units per cc. of serum) among patients } \\
\text { showing a detectable concentration }\end{array}$} \\
\hline & & & 24 hours & 48 hours & 72 hours & 96 hours \\
\hline $\begin{array}{l}300,000 \\
600,000 \\
900,000\end{array}$ & $\begin{array}{r}374 \\
98 \\
21\end{array}$ & $\begin{array}{r}97.0 \\
96.0 \\
100.0\end{array}$ & $\begin{array}{r}0.094 \\
.205 \\
.245\end{array}$ & $\begin{array}{r}0.060 \\
.122 \\
.185\end{array}$ & $\begin{array}{r}0.042 \\
.111 \\
.153\end{array}$ & $\begin{array}{r}0.034 \\
.077 \\
.124\end{array}$ \\
\hline
\end{tabular}

schedule $A$. In spite of the small numbers in each diagnostic category, however, this schedule showed good results, in our opinion, and offered an adaptable regimen for outpatient therapy in early syphilis. No clinical relapses were noted among primary and secondary syphilis patients who remained under observation; and only 2 patients (with secondary syphilis) were re-treated on the basis of serology. By the fifteenth post-treatment month, the cumulative re-treatment rate in the secondary syphilis group was 14.5 percent (probable reinfection rate, 7.1; serologic failure rate, 7.4).

\section{Single-dosage Schedules}

In the next schedule studied, a single dosage of 900,000 units of procaine penicillin $G$ in oil with 2 percent aluminum monostearate was used. Twenty patients were treated for primary or secondary syphilis. Sixteen of the patients were observed at the third post-treatment month, and 10 patients were seen at 15 months. One of the observed group was reinfected at 154 days and was re-treated with the same dosage. After re-treatment, clinical manifestations disappeared and blood tests reverted to negativity for the second time, and remained so. Another patient had positive spinal fluid findings when observed at 448 days; and was re-treated with 600,000 units daily for 6 days. The 900,000-unit schedule was discontinued at our laboratory when it was noted that other investigators were using a slightly larger single dosage-1,200,000 units (20). However, our investigation of single-dosage therapy was continued with smaller amounts of penicillin.

Alexander and Schoch $(21,22)$ and Plotke and associates (23) had shown the dramatic ef- fect of abortive or prophylactic therapy in contacts exposed to active syphilitic infections. We believed that experimentation with a penicillin dosage lower than theirs would yield significant information on the response in syphilis to the therapy generally used for gonorrheal infections. More than 100 patients with early infectious syphilis were treated with a single intramuscular injection of 300,000 units of procaine penicillin in oil with 2 percent aluminum monostearate. Special studies were made of penicillin serum concentrations, clinical and serologic reactions to therapy, and response to re-treatment $(8,19,24)$. Full reports on certain aspects of these studies will be published at a later date. No treatment failures were observed in the seronegative primary syphilis group, but the otherwise high cumulative retreatment rates of the 300,000-unit schedule led to its discontinuance. By 12 months the retreatment rate was 28.4 for secondary syphilis, and 12.7 for seropositive primary syphilis; and additional failures were seen after this period (table 4, schedule B). Nearly all the re-treated cases were true treatment failures, including one with positive spinal fluid findings. However, three significant facts were revealed: $(a)$ seronegative primary syphilis shows adequate response to a single injection of 300,000 units of procaine penicillin $G$ with aluminum monostearate; (b) a large percentage of patients with seropositive primary syphilis can be expected to respond satisfactorily to as little as 300,000 units of this penicillin product; and (c) a single-injection or one-session schedule of intramuscular penicillin therapy can be developed for the cure of early syphilis, dependent upon the determination of the proper dosage of a slowly absorbed compound of the drug.

Serum concentration studies indicated that 
600,000 units of procaine penicillin in oil with 2 percent aluminum monostearate might be expected to produce a more effective therapy than 300,000 units (table 3). To determine the minimal effective dosage for a majority of patientsa matter of extreme importance in areas where penicillin is scarce or expensive-an experimental single-dosage schedule of 600,000 units was set up. Results are inconclusive at this writing because of too few patients and insufficient observation. Eighteen patients with primary or secondary syphilis were treated; 14 of these were seen at the third month and 10 remained under observation at the seventh month. So far no failures or reinfections have been observed among the small group.

\section{Central Nervous System Syphilis}

It has been difficult to evaluate the therapeutic effect of the different penicillin schedules on syphilis of the central nervous system. One of the reasons for the difficulty has been that only a limited number of such patients were admitted for therapy. The results of studies of penicillin concentrations in the blood and spinal fluid have been influential in formulating our current therapy for this complication. In one study (25), penicillin levels in the cerebrospinal fluid were determined on 198 specimens taken from 114 patients at various time intervals during and after a regimen of six daily injections of procaine microcrystal penicillin in oil with 2

Table 4. Treatment of early syphilis with procaine penicillin $\mathbf{G}$ in oil with 2 percent aluminum monostearate

\begin{tabular}{|c|c|c|c|c|c|c|c|c|c|}
\hline \multirow{2}{*}{$\begin{array}{l}\text { Observation period } \\
\text { (months) }\end{array}$} & \multicolumn{3}{|c|}{ Seronegative primary } & \multicolumn{3}{|c|}{ Seropositive primary } & \multicolumn{3}{|c|}{ Secondary } \\
\hline & $\begin{array}{c}\text { Total } \\
\text { cases } \\
\text { observed }\end{array}$ & $\begin{array}{c}\text { Cumulative } \\
\text { percent } \\
\text { re-treated }\end{array}$ & $\begin{array}{c}\text { Percent } \\
\text { sero- } \\
\text { negative }\end{array}$ & $\begin{array}{c}\text { Total } \\
\text { cases } \\
\text { observed }\end{array}$ & $\begin{array}{c}\text { Cumulative } \\
\text { percent } \\
\text { re-treated }\end{array}$ & $\begin{array}{c}\text { Percent } \\
\text { sero- } \\
\text { negative }\end{array}$ & $\begin{array}{c}\text { Total } \\
\text { cases } \\
\text { observed }\end{array}$ & $\begin{array}{c}\text { Cumulative } \\
\text { percent } \\
\text { re-treated }\end{array}$ & $\begin{array}{c}\text { Percent } \\
\text { sero- } \\
\text { negative }\end{array}$ \\
\hline
\end{tabular}

A. $1,800,000$ units $(600,000$ units once daily for 3 days $)$

\begin{tabular}{|c|c|c|c|c|c|c|c|c|c|}
\hline $\begin{array}{l}0-1 \\
1-2 \\
2-3 \\
3-4 \\
4-5 \\
5-6\end{array}$ & $\begin{array}{r}20 \\
19 \\
18 \\
18 \\
18 \\
18 \\
17 \\
17 \\
17 \\
17 \\
16 \\
14 \\
14 \\
14 \\
11 \\
11 \\
5\end{array}$ & $\begin{array}{l}0.0 \\
0 \\
0 \\
0 \\
0 \\
5.6 \\
5.6 \\
5.6 \\
5.6 \\
5.6 \\
5.6 \\
5.6 \\
5.6 \\
5.6 \\
5.6 \\
5.6 \\
5.6\end{array}$ & $\begin{array}{r}95.0 \\
\text { 100. } 0 \\
\text { 100. } 0 \\
\text { 100. } 0 \\
\text { 100. } 0 \\
94.4 \\
94.4 \\
94.4 \\
94.4 \\
94.4 \\
94.4 \\
94.4 \\
94.4 \\
94.4 \\
94.4 \\
94.4 \\
94.4\end{array}$ & $\begin{array}{l}37 \\
35 \\
34 \\
34 \\
33 \\
33 \\
33 \\
33 \\
32 \\
31 \\
31 \\
31 \\
30 \\
27 \\
26 \\
26 \\
11\end{array}$ & $\begin{array}{l}\text { 0. } 0 \\
0 \\
0 \\
0 \\
\text { 3. } 0 \\
6.0 \\
9.0 \\
12.0 \\
12.0 \\
12.0 \\
15.3 \\
15.3 \\
15.3 \\
15.3 \\
15.3 \\
15.3 \\
24.7\end{array}$ & $\begin{array}{r}5.4 \\
34.3 \\
52.9 \\
70.6 \\
78.8 \\
78.8 \\
78.8 \\
78.8 \\
78.5 \\
78.1 \\
78.1 \\
78.1 \\
77.9 \\
80.9 \\
80.8 \\
80.8 \\
75.2\end{array}$ & $\begin{array}{r}31 \\
31 \\
31 \\
29 \\
28 \\
28 \\
27 \\
27 \\
27 \\
26 \\
25 \\
23 \\
23 \\
22 \\
16 \\
14 \\
9\end{array}$ & $\begin{array}{l}0.0 \\
0 \\
0 \\
0 \\
0 \\
7.1 \\
10.8 \\
14.5 \\
14.5 \\
14.5 \\
14.5 \\
14.5 \\
14.5 \\
14.5 \\
14.5 \\
14.5 \\
14.5\end{array}$ & $\begin{array}{r}\text { 0. } 0 \\
3.2 \\
\text { 19. } 4 \\
27.6 \\
42.9 \\
53.6 \\
66.9 \\
74.3 \\
78.0 \\
81.5 \\
81.4 \\
85.4 \\
85.4 \\
85.4 \\
85.4 \\
85.4 \\
85.4\end{array}$ \\
\hline
\end{tabular}

B. 300,000 units-single injection

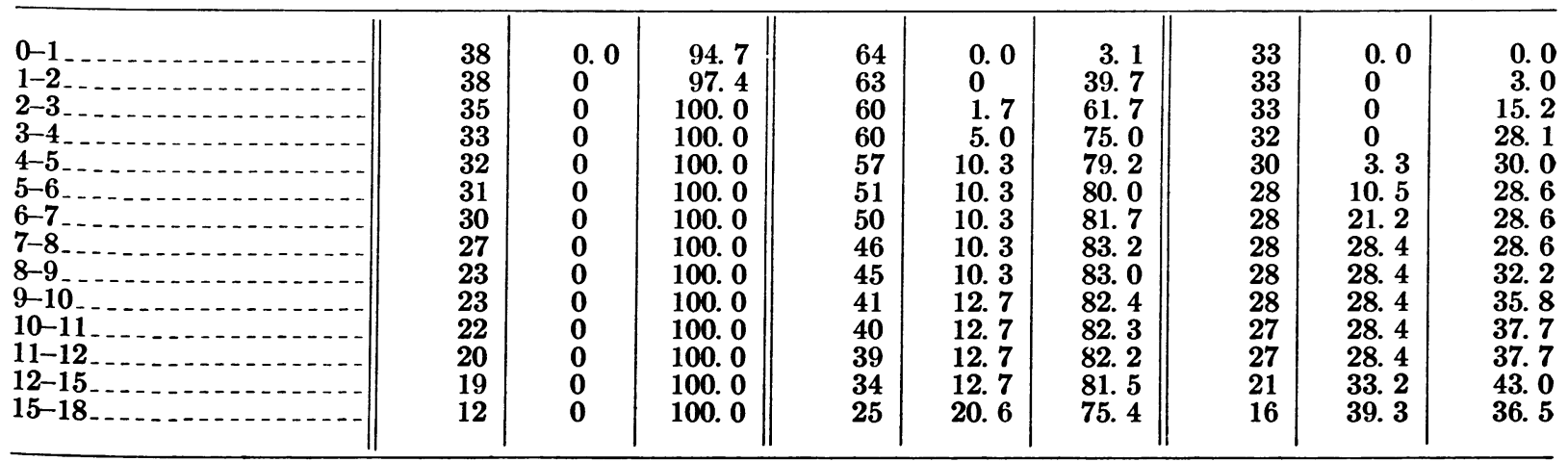


percent aluminum monostearate, in doses of 600,000 units. Detectable levels of penicillin were obtained from 2 to 290 hours after beginning the injections, with 82 percent of the specimens showing a level at 31 hours and 91 percent at 122 hours. Between 31 hours and 194 hours, penicillin was detectable in 75 percent of 110 specimens. On the basis of this and other supporting data $(8)$, we adopted the schedule of 600,000 units for six daily consecutive doses for the treatment of central nervous system syphilis.

Favorable response has been reported by Dattner, Curtis, Stokes, and their co-workers (26-28) and by other authors in nearly all complications of the nervous system when penicillin without adjuvant therapy is used. Research groups in the United States are almost unanimously agreed that arsenic and bismuth are without value as adjuvants to penicillin in the treatment of neurosyphilis. Most investigators also believe that fever therapy should be avoided until penicillin has been proved deficient in a particular case, inasmuch as repeated courses of penicillin in higher amounts have been shown to be effective in a large proportion of both symptomatic and asymptomatic neurosyphilis patients who required additional treatment. - An occasional late serious manifestation of neurosyphilis may require the added support of fever therapy, but the consensus of research observations at this time appears to favor penicillin as the initial course of therapy for most types of neurosyphilis. Long-term evaluative studies in this field should continue to provide definitive answers for all the ramifications of late syphilis.

\section{Spinal Fluid Findings in Early Syphilis}

Abnormal spinal fluid findings were found upon admission in about 7 percent of a large series of patients. These were usually slight deviations from normal in one or more of the test methods employed (Kolmer complementfixation test, Eagle flocculation test, cell count, total protein determination, and colloidal gold reaction). None of the patients showed clinical evidence of central nervous system involvement. After penicillin therapy the spinal fluid became negative and remained negative in all those patients who continued under observation.
Among those patients whose pre-treatment spinal fluid findings were essentially negative, only two were observed later with neurorelapse. Both had secondary syphilis at the time of their original treatment with amorphous penicillin; one with $1,200,000$ units and one with $2,400,000$ units. In both cases we had observed indications of blood serologic relapse just prior to the clinical examinations which revealed the posttreatment positive spinal fluid findings. The first patient returned in the sixth post-treatment month with an acute meningeal type of relapse, and his spinal fluid examination showed the reactions to be: Kolmer 4444-, Eagle positive, colloidal gold 1112220000, cells RBC, globulin normal. After an intensified course of penicillin therapy, he gradually attained negativity in every respect. The second patient returned in the fourth post-treatment month and was retreated with an intensified schedule for serorelapse and asymptomatic neurorelapse (Kolmer 442 \pm - - Eagle positive, colloidal gold 4311100000, other tests normal). He quickly attained and maintained negativity in all tests, in spite of a reinfection for which he was re-treated within the first year.

In the single-dosage schedules using procaine penicillin with aluminum monostearate, two patients were found to have positive spinal fluid tests after therapy. One patient with secondary syphilis treated with a single injection of 900,000 units returned at 448 days with definite laboratory evidence of neurorelapse in all tests, and positive blood test. No spinal fluid examination had been made at the time of original therapy, nor had interim serologic examinations been made. Hence the blood serologic pattern could not be established. The other patient had been treated for primary seropositive syphilis with a single injection of 300,000 units. With no interim examinations and no prior spinal fluid examinations, he was found at 513 days to have a positive blood test, and in the spinal fluid examination the Kolmer test was strongly positive, total protein $42 \mathrm{mg}$. percent, cell count normal, colloidal gold not done.

Among our total patients treated with penicillin for early syphilis, a good proportion have been followed for 3 to 4 years, or longer. Central nervous system involvement has not been observed in any of those patients who have 
shown normal post-treatment progress toward clinical and serologic negativity. There seems to be little reason to expect such involvement after an acceptable schedule of penicillin therapy, since we have observed relatively few cases of neuro-recurrence, regardless of the type of penicillin therapy.

\section{Serologic Observation}

In judging the success or failure of therapy, the ideal serologic follow-up of patients consists of an examination every 2 weeks, or at least every month, for the first 6 to 12 post-treatment months. In the evaluation of an experimental therapy, a battery of qualitative serologic tests and a quantitative test, performed regularly, is advantageous for observation. However, in a public health program or in routine therapy utilizing a schedule known to be effective, essential information may be gained from the regular use of one qualitative and one quantitative test performed preferably with a cardiolipinlecithin antigen.

\section{Failure vs. Reinfection}

Re-treatment rates reported herein include patients who fail to attain cure as well as those who acquire a subsequent syphilitic infection, for in evaluating the various penicillin schedules it has often been difficult to differentiate between relapse and reinfection. It is practically impossible to fulfill all the traditional criteria for reinfection in penicillin-treated patients, because the antibiotic eradicates the infection so quickly that the patient is susceptible to reinoculation within a matter of months, days, or even hours after the termination of therapy. With the exception of certain penicillin schedules which were inadequate as to individual dosage, time interval between injections, or duration of therapy, the true failure rate has been very low. We believe that 60 to 80 percent of our re-treated patients actually had new syphilitic infections, either symptomatic or asymptomatic.

This belief has been strengthened by the results of extensive epidemiological, clinical, and laboratory studies of all re-treated patients. These studies were aimed toward determining whether a patient with a true relapse will relapse a second time when re-treated with the same schedule of penicillin, or whether a favorable result following the administration of a second, identical course of therapy may indicate an asymptomatic reinfection. No report has been published, but the strong impression was gained from collected data that each reinfection can be cured by identical penicillin therapy; however, a true treatment failure will usually relapse again and again when re-treated with the identical schedule, but can be cured by an intensified one.

In patients with early infectious syphilis who have been successfully treated with penicillin, the serologic pattern may be expected to reverse to the negative state, usually within the first year. The rapidity of reversal is apparently dependent upon the stage and duration of the infection at the start of treatment and individual differences in immunological response. The unsuccessfully treated patient, when observation has been adequate, will usually show definite evidence of serologic relapse within 6 months following treatment; and clinical relapse may subsequently occur unless retreatment is instituted promptly.

A patient with a suspected serologic relapse should be carefully observed to be sure that the sustained rise in titer is attributable to syphilis rather than to some acute intercurrent infection. Once a diagnosis of serologic relapse has been confirmed, penicillin therapy should be administered at once; otherwise, serologic progress to negativity may be delayed for months or even years.

\section{Reinfections}

Theoretically, a perfect schedule of therapy should result in 100-percent cure of all cases of syphilis. In such a situation, all reappearances of syphilis in the treated group would be reinfections. If it is correct that immunity to syphilis is a function of systemic exposure to the spirochete in terms of time and numbers of spirochetes, then patients whose original diagnosis was seronegative primary syphilis would have very little immunity and therefore would be readily susceptible to reinfection. Patients with seropositive primary syphilis would have 

and for an inadequate schedule

\begin{tabular}{|c|c|c|c|c|c|c|c|}
\hline \multirow[b]{2}{*}{ Schedule of therapy } & \multirow[b]{2}{*}{ Stage of syphilis } & \multirow[b]{2}{*}{ Total cases } & \multirow{2}{*}{$\begin{array}{l}\text { Number } \\
\text { observed } \\
12 \text { to } 15 \\
\text { months }\end{array}$} & \multicolumn{3}{|c|}{ Cumulative percent } & \multirow[b]{2}{*}{$\begin{array}{l}\text { Total case } \\
\text { re-treated }\end{array}$} \\
\hline & & & & $\begin{array}{c}\text { Re-trcater } \\
\text { on basis of } \\
\text { serology } \\
\text { only }\end{array}$ & $\begin{array}{l}\text { Clinical } \\
\text { relapse }\end{array}$ & $\begin{array}{c}\text { Probable } \\
\text { reinfection }\end{array}$ & \\
\hline $\begin{array}{l}\text { Single injection of } 300,000 \text { units } \\
\text { procaine penicillin with alumi- } \\
\text { num monostearate. }\end{array}$ & $\left\{\begin{array}{l}\text { Seronegative pri- } \\
\text { mary } \\
\text { Seropositive primary } \\
\text { Secondary }\end{array}\right.$ & $\begin{array}{l}38 \\
64 \\
33\end{array}$ & $\begin{array}{l}19 \\
34 \\
21\end{array}$ & \begin{tabular}{r|}
0 \\
7.5 \\
22.7
\end{tabular} & $\begin{array}{r}0 \\
1.8 \\
10.5\end{array}$ & $\begin{array}{l}0 \\
3.5 \\
0\end{array}$ & $\begin{array}{c}0 \\
12.7 \\
33.2\end{array}$ \\
\hline $\begin{array}{l}7,200,000 \text { units of aqueous peni- } \\
\text { cillin (200,000 units every } 2 \\
\text { hours for } 3 \text { days). }\end{array}$ & $\left\{\begin{array}{l}\text { Seronegative pri- } \\
\text { mary. } \\
\text { Seropositive primary } \\
\text { Secondary }\end{array}\right.$ & $\begin{array}{r}110 \\
176 \\
89\end{array}$ & $\begin{array}{r}86 \\
133 \\
62\end{array}$ & $\begin{array}{l}0 \\
0 \\
1.5\end{array}$ & $\begin{array}{r}2.0 \\
.6 \\
1.1\end{array}$ & $\begin{array}{l}\text { 6. } 0 \\
2.6 \\
1.4\end{array}$ & $\begin{array}{l}\text { 8. } 0 \\
\text { 3. } 1 \\
\text { 4. } 0\end{array}$ \\
\hline
\end{tabular}

some immunity and hence be less liable to reinfection. Patients with secondary syphilis would have developed considerable immunity and would be still less liable to reinfection. Following this line of reasoning, it can be expected that the better schedules of treatment would show a higher re-treatment rate in the primary stage than in the secondary. A comparison of these factors in two of our schedules lends force to the argument. In table 5 are shown the cumulative re-treatment rates by stage of disease for a very successful schedule of treatment $(7,200,000$ units of aqueous penicillin administered in doses of 200,000 units every 2 hours) and for an inadequate schedule of treatment (a single injection of 300,000 units of procaine penicillin with aluminum monostearate). In the former schedule, the cumulative failure rate decreases from primary to secondary; whereas in the latter schedule, it increases from primary to secondary.

\section{Summary}

1. Penicillin, as the sole therapeutic agent, can cure early syphilis.

2. Adequate concentration of penicillin must be maintained in the host for at least 3 days.

3. Definite evidence of serologic relapse will usually develop in the unsuccessfully treated patient within the first six post-treatment months, and clinical manifestations may develop if this relapse is not promptly re-treated.

4. A more intensified regimen than the original șchedule is usually necessary for successful re-treatment of clinical and serologic re- lapse. Collected data indicates, however, that a reinfected patient may be cured by therapy identical to the original schedule, provided central nervous system involvement has not occurred.

5. Abnormal spinal fluid findings are observed in relatively few patients after an acceptable schedule of penicillin therapy for early syphilis. The clinician's suspicion of such involvement should be aroused by serologic relapse or resistance.

6. A single-dosage schedule of sparingly soluble penicillin in a satisfactory repository vehicle will eventually, in our opinion, be found to be therapeutically effective in early syphilis.

7. A successful schedule of penicillin therapy can be expected to show a higher cumulative re-treatment rate among early primary cases than among secondary cases; whereas an inadequate schedule of penicillin therapy will show a higher re-treatment rate among secondary cases than among primary cases.

\section{ACKNOWLEDGMENT}

The authors acknowledge the technical assistance of the therapy evaluation unit of the office of statistics, Division of Venereal Disease, Public Health Service.

\section{REFERENCES}

(1) Mahoney, J. F., Arnold, R. C., and Harris, A.: Penicillin treatment of early syphilis. A preliminary report. J. Ven. Dis. Inform. 24: 355-357 (1943).

(2) Mahoney, J. F., Arnold, R. C., and Harris, A.: Penicillin treatment of early syphilis-first 
four patients after 6 years. J. Ven. Dis. Inform. 30 : 350-355 (1949).

(3) Mahoney, J. F., Arnold, R. C., Sterner, B. L., Harris, A., and Zwally, M. R.: Penicillin treatment of early syphilis, II. J. A. M. A. 126: 63-67 (1944).

(4) Sternberg, T. R., and Leifer, W.: Treatment of early syphilis with penicillin. J. A. M. A. 133: 1-5 (1947).

(5) U. S. Public Health Service : Rapid treatment of early syphilis. Progress report (see tables 20 and 22). Washington, D. C., Public Health Service, 1948.

(6) Iskrant, A. P., Bowman, R. W., and Donohue, J. F.: Techniques in evaluation of rapid antisyphilitic therapy. Pub. Health Rep. 63: 965977 (1948).

(7) Bauer, T. J., and Price, E. V.: Results of therapy by race, sex, and stage of syphilis. J. Ven. Dis. Inform. 30: 1-7 (1949).

(8) Thayer, J. D., Bucca, M. A., and Walker, A. I.: Penicillin blood and spinal fluid levels in man by various schedules of aqueous and repository penicillins. (To be published.)

(9) Arnold, R. C., Mahoney, J. F., Cutler, J. C., and Levitan, S.: Penicillin therapy in early syphilis, III. J. Ven. Dis. Inform. 28: 241-244 (1947).

(10) Bundesen, H. N., Loewe, L., Craig, R. M., Schwemlein, G. X., Barton, R. L., and Bauer, T. J. : Therapy of early syphilis with massive doses of penicillin. Arch. Dermat. \& Syph. 56: 339343 (1947).

(11) Arnold, R. C., Mahoney, J. F., and Cutler, J. C. : Reinfection in experimental syphilis in rabbits following penicillin therapy. I. Reinfection in early infectious syphilis. Am. J. Syph., Gonor. \& Ven. Dis. 31 : 264-267 (1947).

(12) Arnold, R. C., Mahoney, J. F., and Cutler, J. C.: Reinfection in experimental syphilis in rabbits following penicillin therapy. II. Reinfection in early latent syphilis. Am. J. Syph., Gonor. \& Ven. Dis. 31 : 489-492 (1947).

(13) Arnold, R. C., Mahoney, J. F., Nicholson, F. P., and Wright, R. D.: Penicillin therapy of early syphilis, IV. J. Ven. Dis. Inform. 30: 125-127 (1949).

(14) Romansky, M. J., and Rittman, G. E.: A method of prolonging the action of penicillin. Science 100: 196-198 (1944).

(15) Thomas, E. W., Landy, S., and Cooper, C.: Rapid treatment of early syphilis with penicillin in beeswax and oil. J. Ven. Dis. Inform. 28: 19-23 (1947).

(16) Romansky, M. J., and Rein, C. R.: Treatment of early syphilis with calcium penicillin-oil-beeswax. J. A. M. A. 132: 847-851 (1946).

(17) Chargin, L., Sobel, N., Rein, C., and Rosenthal, T. : Treatment of early syphilis with penicillin injection in oil and wax U. S. P. Report of 153 cases. Arch. Dermat. \& Syph. 59: 595-602 (1949).

(18) Buckwalter, F. H., and Dickison, H. L.: A new absorption delaying vehicle for penicillin. J. Am. Pharm. A. (Scient. ed.) 37: 472-474 (1948).

(19) Wright, R. D., Nicholson, F. P., Mahoney, J. F., and Arnold, R. C.: The treatment of early syphilis with three injections of penicillin and with one injection of penicillin. In A symposium on current progress in the study of venereal diseases. Washington, D. C., 1949, pp. 28-34.

(20) Thomas, E. W., Rein, C. R., Landy, S., and Kitchen, D. K. : Results of single and multiple injection schedules for the treatment of early syphilis with penicillin in oil and aluminum monostearate. Am. J. Syph., Gonor. \& Ven. Dis. 34 : 331-337 (1950).

(21) Alexander, L. J., and Schoch, A. G.: Results of treatment of over 100 contacts of patients with early syphilis with a "one-day abortive cure." In Recent advances in the study of venereal diseases. A symposium. Raleigh, N. C., 1948, pp. 263-266.

(22) Alexander, L. J., and Schoch, A. G.: Prevention of syphilis. Penicillin calcium in oil and white wax, U. S. P. bismuth ethylcamphorate and oxophenarsine hydrochloride in treatment, during incubation stage, of persons exposed to syphilis. Arch. Dermat, \& Syph. 59: 1-10 (1949).

(23) Plotke, F., Eisenberg, H., Baker, A. H., and Laughlin, M. E.: Penicillin in the abortive treatment of syphilis. J. Ven. Dis. Inform. 30: 252-256 (1949).

(24) Wright, R. D., Nicholson, F. P., and Arnold, R. C.: Treatment of early syphilis with three injections of penicillin and with one injection of penicillin, II. J. Ven. Dis. Inform. 31: 235240 (1950).

(25) Wright, R. D., Thayer, J. D., Nicholson, F. P., and Arnold, R. C.: Penicillin levels in spinal fluid after intramuscular injection of procaine penicillin. J. Ven. Dis. Inform. 32: 39-42 (1951).

(26) Dattner, B., Kaufman, S. S., and Thomas, E. W.: Penicillin in the treatment of neurosyphilis. Arch. Neurol. \& Psychiat. 58: 426-435 (1947).

(27) Curtis, A. C., Horne, S. F., and Norton, D. H. : Neurosyphilis: Evaluation after two years of treatment with penicillin alone and with a conbination of penicillin and malaria. Am. J. Syph., Gonor. \& Ven. Dis. 32: 546-564 (1948).

(28) Stokes, J. H., Falk, M. S., and Gammon, G. D.: Long-term results in neurosyphilis treated with penicillin alone. Am. J. Syph., Gonor. \& Ven. Dis. 32: 521-545 (1948). 